\title{
Major Salivary Gland Cancer pT1 TNM Finding v8
}

National Cancer Institute

\section{Source}

National Cancer Institute. Major Salivary Gland Cancer pT 1 TNM Finding v8. NCI

Thesaurus. Code C132747.

Major salivary gland cancer with tumor $2 \mathrm{~cm}$ or less in greatest dimension without extraparenchymal extension. Extraparenchymal extension is clinical or macroscopic evidence of invasion of soft tissues. Microscopic evidence alone does not constitute extraparenchymal extension for classification purposes. (from AJCC 8th Ed.) 